Omni-Akuatika, 13 (2): 39-47, 2017
ISSN: 1858-3873 print / 2476-9347 online
Research Article

\title{
Biocapacity in the Gili Matra Region: A Spatial Assessment of the Carrying Capacity of Small Islands
}

\author{
Fery Kurniawan $^{\left.1,5^{*}\right)}$, Luky Adrianto ${ }^{2,5}$, Dietriech G. Bengen ${ }^{3}$, Lilik Budi Prasetyo ${ }^{4}$ \\ ${ }^{1)}$ Graduate School of Coastal and Marine Resources Management, Faculty of Fisheries and Marine Sciences, \\ Bogor Agricultural University ( IPB), Indonesia \\ ${ }^{2)}$ Department of Aquatic Resources Management, Faculty of Fisheries and Marine Sciences, Bogor Agricultural \\ University (IPB), Indonesia \\ ${ }^{3)}$ Department of Marine Sciences and Technology, Department of Aquatic Resources Management, Faculty of \\ Fisheries and Marine Sciences, Bogor Agricultural University (IPB), Indonesia \\ ${ }^{4)}$ Department of Forest Resources Conservation and Ecotourism, Faculty of Forestry, Bogor Agricultural \\ University (IPB), Indonesia \\ ${ }^{5)}$ Center for Coastal and Marine Resources Studies, Bogor Agricultural University (IPB), Indonesia
}

"Corresponding author: kurniawan.madura@gmail.com

Received 5 April 2017; Accepted 4 July 2017; Available online 27 November 2017

\begin{abstract}
Spatial as a contributor to biological productivity and ecosystem services have not been considered in the sustainable development of small islands. The aim of this study to appraise biocapacity (BC) in the Gili Matra Islands to estimate the existing carrying capacity for sustainable development, and refines the current BC methodology that emphasizes the spatial aspects in small islands. Based on analysis results, the Gili Matra Islands have BC total ranging from 659.46 to 1,069.57 gha in 2010, and increased from 673.64 to $1,093.02$ gha in 2014. The highest total BC is the Gili Trawangan Island, while the lowest is the Gili Meno Island, but for the local BC is the opposite. The total local BC per island can be supplied around 0.00857 gha per capita for the Gili Ayer Island, 0.20103 gha per capita for the Gili Meno Island, and 0.00344 gha per capita for the Gili Trawangan Island. They are influenced by total persons or demanders. The BC values indicate a critical position, both per-unitarea or per-capita, which is spatially nearly $100 \%$ of the needs supplied from outside the island, and demonstrate the use on the Gili Matra Region have exceeded the existing carrying capacity. The sustainable development aspects and land use management should be applied strictly to ensure the sustainability of natural resources, social and economic, as well as cotinuously consider the efforts and existing strategies of conservation. The export and import factors of bioproductivity should be considered in making long-term planning. Spatially, BC appraisal was applicable to illustrate the condition of an area on the small islands. The GIS based BC can give the information of pattern of changes and distributions, both spatial and temporal. However, the statistical data use is needed to get the value of $B C$ per capita.
\end{abstract}

Keywords: Biocapacity; carrying capacity; sustainability; small island; Gili Matra

\section{Introduction}

Space as the supply of ecosystem services to the needs of human life continues to increase, both globally and locally (Kissinger and Rees, 2010; Borucke et al., 2013). National Footprint Accounts (NFAs), 2016 edition calculated and reported that the worlds have undergone a deficit in a biocapacity of 1.1 gha per capita, and the trend shows decline continously year by year (GFN, 2016), or overshoot. This condition is very worrying because it is also accompanied by an increase in ecological footprint value (EF). Global overshoot indicates that ecologcal stocks are decreasing and/or that waste is accumulating, which requires enormous energy in its processing (Borucke et al., 2013; Cornelia, 2014). . 
Table 1. Islanders, tourist and total population in the Gili Matra Islands

\begin{tabular}{lrrrrrr}
\hline \multirow{2}{*}{ Islands } & \multicolumn{2}{c}{ Islanders $^{1}$} & \multicolumn{2}{c}{ Tourists $^{2}$} & \multicolumn{2}{c}{ Total demander $^{\text {a }}$} \\
\cline { 2 - 7 } & \multicolumn{1}{c}{2010} & \multicolumn{1}{c}{2014} & \multicolumn{1}{c}{2014} & \multicolumn{1}{c}{2010} & \multicolumn{1}{c}{ (14 } \\
\hline Gili Ayer & 1,542 & 1,606 & 9,387 & 85,156 & 10,929 & 86,762 \\
Gili Meno & 530 & 551 & 4,446 & 32,959 & 4,976 & 33,510 \\
Gili Trawangan & 1,503 & 1,549 & 210,283 & 315,959 & 211,786 & 317,508 \\
Total & 3,575 & 3,706 & 224,116 & 434,074 & 227,691 & 437,780 \\
\hline
\end{tabular}

Sources: 'Desa Gili Indah/Gili Indah Village (2015); ${ }^{2}$ Dinas Pariwisata Lombok Utara/Department of Tourism of Lombok Utara Regency (2015).

Noted: ${ }^{\mathrm{a}}=$ user of biological capacity on the islands.
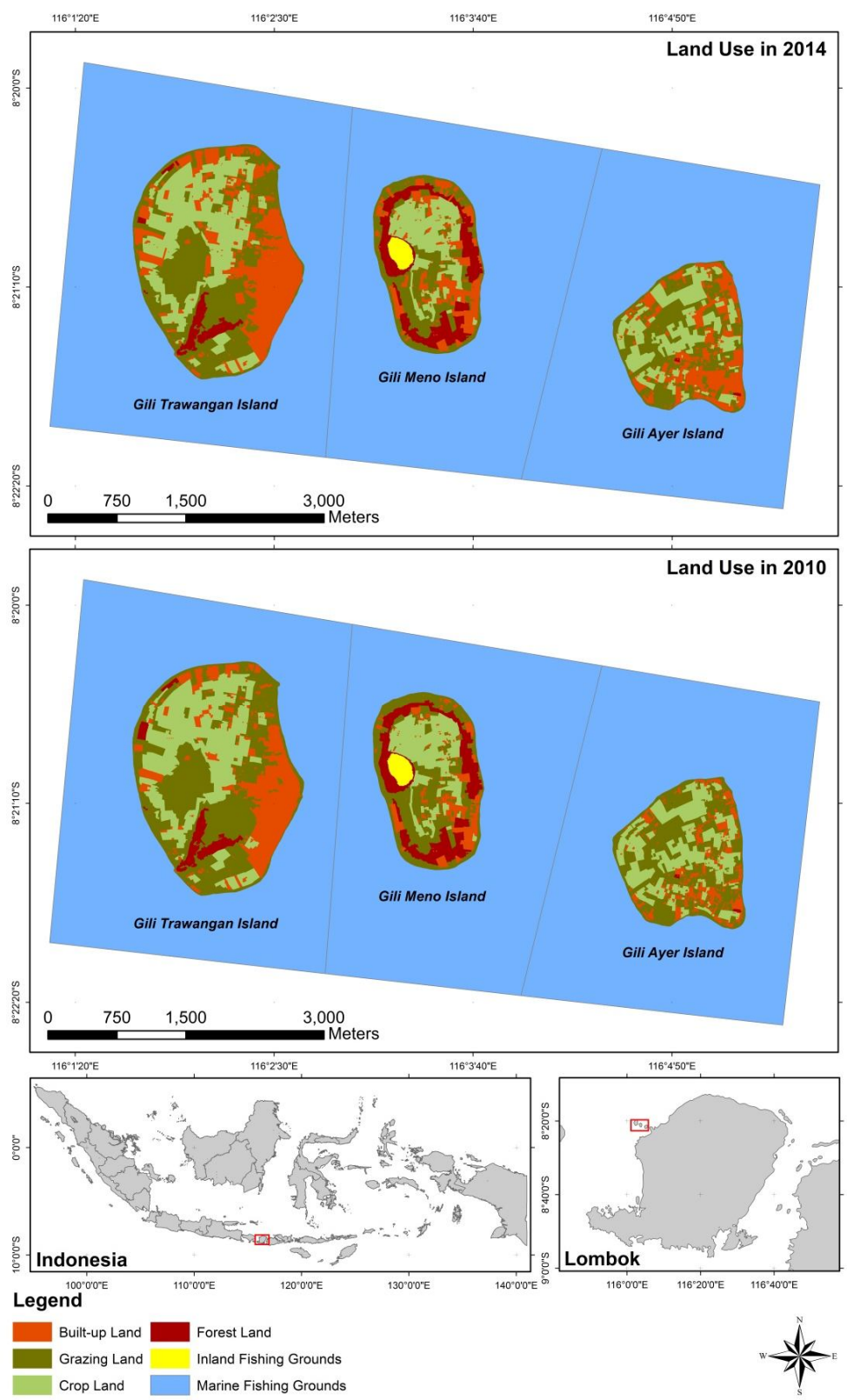

Figure 1. Maps of land use in the Gili Matra Islands in 2010 and 2014 
Locally, BC represents the endowment of ecologically productive region and indicates the ecosystems potential capacity to provide natural resources and services (Bagliani et al., 2008; Toderoiu, 2010) and the indicators of ecosystem wellbeing and vulnerability (Vačkár̆, 2012). BC calculation is very important to ensure that the range of land productivity and supply that can be provided by a region based on productive land categories (Bagliani et al., 2008; Toderoiu, 2010; Yue et al., 2011). BC may also provide geographical wealth information regarding the distribution and use of ecological resources and ecosystem services (Bagliani et al., 2008; Borucke et al., 2013). However, to date, BC is only seen as a supportive part of the EF analysis, so it is not analyzed and discussed in detail, merely a comparison (Bagliani et al., 2008; Toderoiu, 2010; Vačkáŕ, 2012).

Assessment of BC is mostly done and limited by the administrative area (Bagliani et al., 2008; Toderoiu, 2010; Yue et al., 2011; Hopton and White, 2012; Niccolucci et al., 2012; Borucke et al., 2013; Galli et al., 2014). This is related to the availability of existing data (Hopton and White, 2012), where the data source used is regional statistical data, whereas in the level of the smaller ecological space, especially with the specific and massive utilization rate should be assessed in detail and precisely to ensure the carrying capacity and sustainability of existing activities and resources, as suppliers of all needs (Rees, 1992). For that, spatial analysis can be done to help estimate the carrying capacity and existing needs, to understand the economic, social and environmental interactions, and sustainable policies (Erb, 2004; Kissinger and Rees, 2010; Yue et al., 2011; Niccolucci et al., 2012), both spatially and temporarily.

Small islands have the limited space and resources and relatively homogenous types, and have a high dependence on imports, making them vulnerable to global, regional and local influences (Adrianto and Matsuda, 2004; Farhan and Lim, 2012; Kurniawan et al., 2016b). Bagliani et al. (2008) states that That spatial heterogeneity greatly affects the value of $\mathrm{BC}$ and EF of a region. Heterogeneity is also indirectly strongly associated with natural diversity (Wrbka et al., 2004). Meaning, the more homogeneous the space will make the limited kind of supply provided, and can affect the sustainable development (Shia et al., 2004; Bagliani et al., 2008; Yue et al., 2011). The aim of this study to appraise BC in the Gili Matra Islands to estimate the existing carrying capacity for sustainable development. The paper tries to refine the current BC methodology that emphasizes the spatial aspects in small islands.

\section{Material and Methods}

\section{Study area}

The Gili Matra Islands are the National Marine Conservation Area, Marine Tourism Park. Administratively, the Gili Matra Islands consisting of Gili Ayer Island, Gili Meno Island and Gili Trawangan Island are located in Gili Indah Village, Pemenang District, North Lombok Regency, West Nusa Tenggara Province (Figure 1). The islands have a relatively dense population. In 2014, the islanders are recorded to reach 3,706 inhabitants, spread over Gili Ayer Island of 1,606 inhabitants, Gili Trawangan Island of 1,549 inhabitants, and Gili Meno Island of 551 inhabitants (Table 1) (the primary data of Desa Gili Indah/Gili Indah Village, 2015).

Presently, the main activity of regional development is marine tourism. As one of the most popular destinations in the world, Gili Matra's favorite tourist activities include diving, snorkeling, sun bathing, swimming, boating, fishing, surfing and viewing. The number of tourist arrivals, both from domestic and foreign tourists reached 434,074 tourists in 2014. The largest number of tourists are on Gili Trawangan Island, which is 315,959 tourists, followed by Gili Ayer- and Gili Meno Island, respectively, 85,156 and 32,959 tourists (Table 1) (the primary data of Dinas Pariwisata Lombok Utara/Department of Tourism of Lombok Utara Regency, 2015). In the ecological perspective, specifically, the demander total of biological capacity in one year reached 437,780 people, and the number show a high increase when compared with the number of islanders and tourist visits in 2010 (Table 1).

\section{Biocapacity}

Biocapacity (biological capacity) is the ecosystem capacity to produce useful biological materials and to absorb waste material made by humans, using existing management and technology extraction schemes. Useful biological material is defined as all things used on the basis of human economy (Ewing et al., 2010; Lin et al., 2016). BC is influenced by two factors, namely the productive area of land and waters, and the productivity of the area as measured by the number of production per hectare (Toderoiu, 2010). Therefore, consideration of "use" may change from year to year. 
Table 2. Yield factor of Indonesia and equivalence factor for biocapacity calculation

\begin{tabular}{lrc}
\hline \multicolumn{1}{c}{ Land Use Types } & $\mathrm{YF}^{1}$ & $\mathrm{EQF}^{2}$ \\
\hline Crop land & 0.986381385 & 2.51 \\
Grazing land & 2.799676898 & 0.46 \\
Marine fishing grounds & 1.376646079 & 0.37 \\
Inland fishing grounds & 1 & 0.37 \\
Forest land & 0.613165885 & 1.26 \\
Built-up land & 0.986381385 & 2.51 \\
\hline
\end{tabular}

Sources: ' $\mathrm{GFN}$ (2016); ${ }^{2} \mathrm{EQF}$ in 2007 (Ewing et al., 2010).

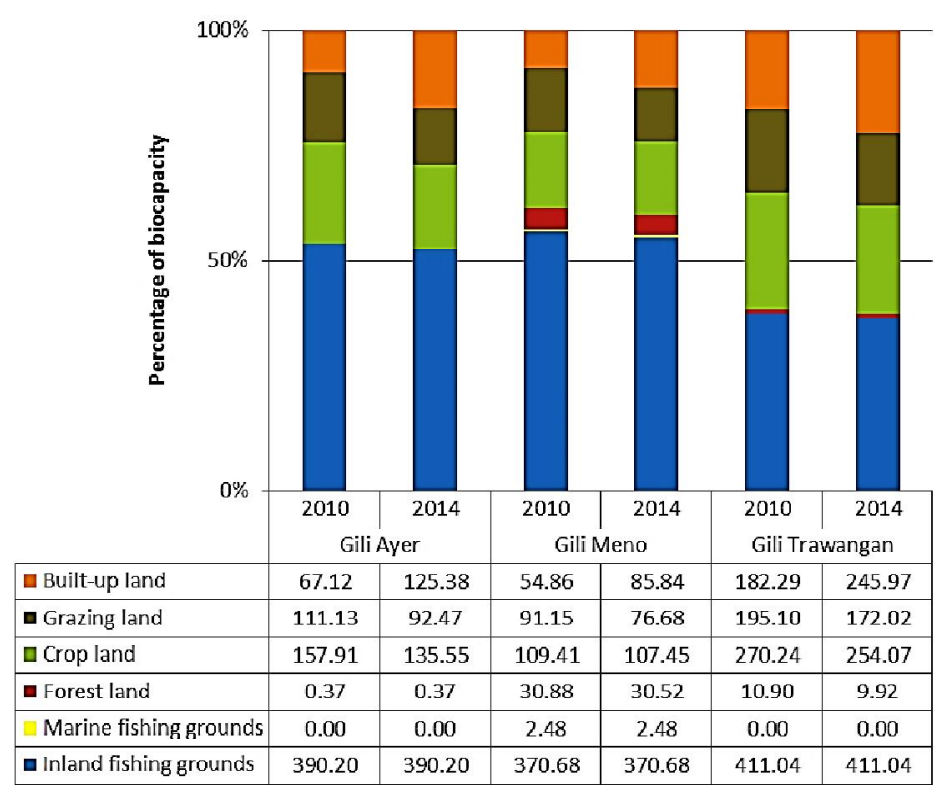

Figure 2. The percentage of distributions and biocapacity changes in the Gili Matra Region in 2010 and 2014

\section{Data analysis and calculation}

The land use spatial data of islands were derived from the interpretation and analysis of the Quickbird satellite imagery in 2010 and the GeoEye satellite imagery in 2014. Data were built by digitazion on screen. Field survey and ground checkpoint were conducted for the validation and classification of each land use types. For waters area data obtained from the waters area of the National Marine Conservation Area of the Gili Matra Islands, which is divided for each island based on the distance between islands and divided by two. All spatial data are categorized and calculated by land use types for BC analysis (Ewing et al., 2010; Lin et al., 2016) using GIS-analysis on attribute table.

Based on GIS analysis results, then BC is calculated using the following equation (Scotti et al., 2009; Ewing et al., 2010; Borucke et al., 2013):

$$
B C=\sum_{i=1}^{n} A_{p, i} \cdot Y F_{i} \cdot E Q F_{i}
$$

where, $A_{p, l}$ is the area available on the island $p$ for for a given land uses types $i$ (ha), whereas $Y F_{i}$ and $E Q F_{i}$ are the yield factor and equivalence factor, respectively, for each land use types $i$ (gha), in this case YF for Indonesia.

To get local $\mathrm{BC}\left(B C_{l}\right)$ (gha per capita and gha per capita per year), $B C$ total value is divided by the person number $(P)$. It includes both islanders and tourists, so the amount of spatial contribution per ha to support the needs per person available can be obtained, as stated in the following equation:

$$
B C_{l}=\frac{B C}{\sum P}
$$

\section{Yield and equivalence factors}

Yields Factors (YFs) are the ratio of the average yield of the area of each land use type utilized per year from a region, compared to the larger region (Lin et al., 2016). They may reflect natural factors such as differences in precipitation or soil quality, as well as differences in anthropogenic factors, including 
management practices (Borucke et al., 2013). Base on assessment from Global Footprint Network 2016 (GFN, 2016), in Indonesia, the highest YF value is in the category of grazing land (2.79), followed by marine fishing grounds (1.37) and inland fishing grounds (1.00) (Table 2). YF can be measured based on local yield to get more real time results (Mózner et al., 2012).

Equivalence Factors (EQFs) reflect the areas provided or required from each specific land use types into the equivalent areas of the global average bioproductivity of different land use categories (global hectares) (Table 2) (Borucke et al., 2013; Lin et al., 2016). EQFs are the same for all countries, and change slightly from year to year. They are calculated using suitability indexes from the Global AgroEcological Zones (GAEZ) model, combined with information about actual areas of cropland, forest, and grazing area from FAOSTAT (see Lin et al., 2016).

\section{Results}

\section{Land use types of biocapacity}

Land use types of Gili Matra Islands are categorized into six categories, i.e. built-up land (including settlement area, tourism accommodation, and islander and tourism supporting infrastructure), grazing land (including pastures, beach area and open area with vegetation), crop land (consist of unirrigated agricultural field and plantation area), forest land (including mangrove forests and mixed forests dominated by large bushes and lowland plants), marine fishing grounds, and inland fishing grounds (Figure 1).

The comparasion results of spatial analysis in 2010 and 2014 can be explained as follows:

1) Built-up land

Build-up land is a land use that many additions, mainly for tourist accommodation. In the Gili Ayer Island increased area reached around $86.79 \%$ (23.53 ha) from 27.11 ha in 2010 to 50.64 ha in 2014. The increase also occurred in the Gili Meno Island, from 22.16 ha in 2010 to 34.67 ha in 2014, or increased by $56.45 \%$ (12.51 ha). As well as in the Gili Trawangan Island, where the growth area about $34.93 \%$ (25.72 ha) from 73.63 ha in 2010 to 99.35 ha in 2014.

2) Grazing land

Grazing land is the most dominant land use on the Gili Matra Islands, however also that has the highest decreasing area trend.
Currently, the land used by communities to graze livestock, such as goats and cows, as well as a source of feed for the horses to be one means of transportation of people and goods, and become one of the tourism activities of the island. In the Gili Ayer- and Gili Meno Island the decrease of the area about $16.79 \%$ (14.49 ha), or from 86.29 ha in 2010 to 71.80 ha in 2014 , and $15.88 \%$ (11.24 ha) from 70.78 ha in 2010 to 59.4 ha in 2014 , respectively. The largest decrease occurred in the Gili Trawangan Island, which is 17.92 ha (11.83\%) from 151.49 ha in 2010 to 133.57 ha in 2014 .

3) Crop land

Crop land is dominated by the coconut plantation, however, it is not a primary livelihood, because the communities have turned into a tourism actors. In some areas, there are still cultivated fields that are planted with maize and other crops types. The land use category is the second largest decline. In the Gili Ayer Island, the area is reduced to 9.03 ha, or $14.16 \%$ from 2010 (63.78 ha) to 2014 (54.75 ha). Similarly in the Gili Trawangan Island, decreased by 6.53 ha (5.98\%) from 2010 (109.15 ha) until 2014 (102.62 ha). Whereas, for the Gili Meno Island is relatively constant, the decrease is only about 0.79 ha $(1.79 \%)$, from 44.19 ha in 2010 to 43.40 ha in 2014 .

4) Forest land

Forest land is the least affected land use, although on the Gili Trawangan Island is still relatively large, that is about 1.27 ha $(9.00 \%)$, changing from 14.11 ha in 2010 to 12.84 ha in 2014. Actually, the Gili Trawangan Island had a mangrove forest area, nonetheless, curently, it has been exhausted and canged into built-up area. For the Gili Meno Island, the area decreased by 0.47 ha $(1.18 \%)$ from 39.97 ha in 2010 to 39.50 ha in 2014, while for Gili Ayer Island has not changed.

5) Marine fishing grounds

The National Marine Conservation Area of the Gili Matra Islands has not changed in several years, so there is no change to the water area, either in each island. The land type of marine fishing grounds is 766,07 ha for the Gili Ayer Island, 727,74 for the Gili Meno Island and 806,97 ha for the Gili Trawangan Island.

6) Inland fishing grounds

Inland fishing grounds is located only on the Gili Meno Island, called the salt water lake, which is about 6.70 ha. Over the past four years, the area has not changed. Nowadays, the lake is used as a source of salt and mangrove and lake attractions. 
Table 3. Total and local biocapacity in the Gili Matra Islands

\begin{tabular}{lrrrrrr}
\hline & \multicolumn{2}{c}{ Gili Ayer Island } & \multicolumn{2}{c}{ Gili Meno Island } & \multicolumn{2}{c}{ Gili Trawangan Island } \\
\cline { 2 - 7 } & 2010 & 2014 & 2010 & 2014 & 2010 & 2014 \\
\hline Biocapacity (gha) & 726.73 & 743.97 & 659.46 & 673.64 & $1,070.57$ & $1,092.73$ \\
Biocapacity of islander (gha per capita per year) & 0.47129 & 0.46324 & 1.24427 & 1.22258 & 0.71229 & 0.70544 \\
Biocapacity of tourist (gha per capita per year) & 0.07742 & 0.00874 & 0.14833 & 0.02044 & 0.00509 & 0.00346 \\
Biocapacity of demander (gha per capita per year) & 0.0665 & 0.00857 & 0.13253 & 0.20103 & 0.00505 & 0.00344 \\
\hline
\end{tabular}

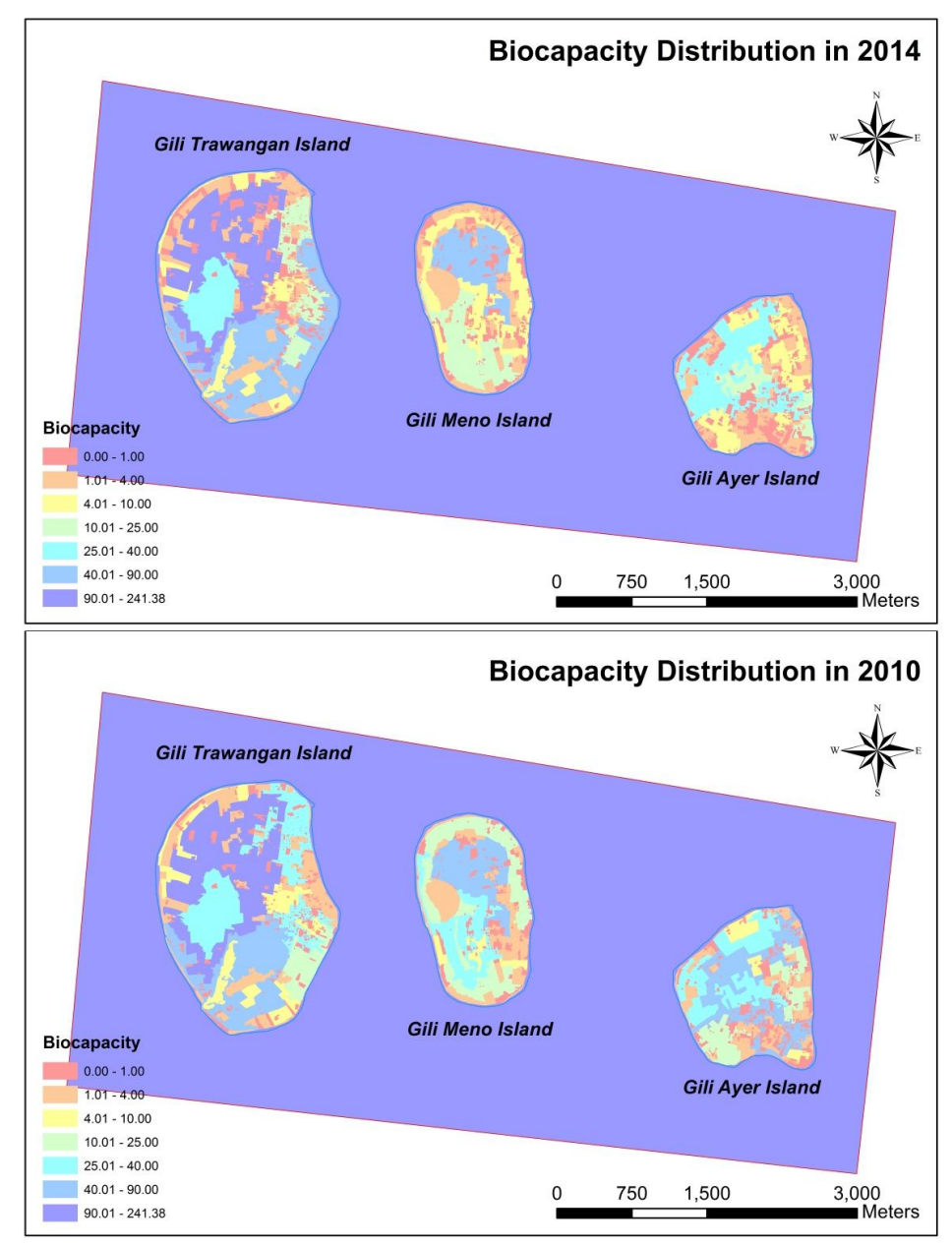

Figure 3. Maps of biocapacity distributions in the Gili Matra Region in 2010 and 2014

\section{Biocapacity}

As shown in Table 3, the $\mathrm{BC}$ total in the Gili Matra Region ranged from 659.46 to $1,069.57$ gha in 2010 , and the range increased from 673.64 to $1,093.02$ gha in 2014. The highest BC was owned by the Gili Trawangan Island, while the lowest was the Gili Meno Island.

Based on land use types in the islands (Figure 2), the largest BC contributor for all islands in the Gili Matra Region is the crop land category, ranging from 107.45 to 254.07 gha. The greatest changes occured in the grazing land category. In 2010, grazing land had the second largest BC after crop land, ranging from 91.15 to $195.10 \mathrm{gha}$, however, changed into the third contributor in 2014, ranging from 76.68 to 172.02 gha. So, in 2014, the second BC contributor is built-up land, ranging from 85.84 to 245.97 gha.

It is different in the forest land category. The category is the smallest contributor of $\mathrm{BC}$ in all islands, ranging from 0.37 to 30.52 gha, and the amount was relatively fixed. This is reasonable for in small islands. The condition is similar in the waters area. The total waters BC do not change from year to year, because there 
is no amendment in the status of the designated area. For the fishing grounds, the total $\mathrm{BC}$ reach $1,174 \mathrm{gha}$, consist of marine fishing grounds of $1,171.92$ gha and inland fishing grounds of 2.48 gha (Figure 2).

\section{Discussion}

The tourism development made rapid changes to the landscape on the island, especially for settlement, tourist accomodation and tourism fasilities (Hampton and Jeyacheya, 2014; Kurniawan et al., 2016a). These changes make the island's landscape fragmented and homogeneous (Kurniawan et al., 2016a), thus reducing the naturalness and beauty of the island. In the Gili Matra, tourism accommodation development has been started since the early 1980s, whose development began from the island of Gili Trawangan (Bottema and Bush, 2012). Generally, the changes are located around the centers of community and tourism activities, particularly in the areas close to inter-island ports and supporting facilities of tourism (Figure 3).

The land uses changes have affected the value of present $\mathrm{BC}$. Based on distributions, in Figure 3 shown many areas that have decreased the BC value from year 2010 to 2014, especially in the Gili Meno- and Ayer Island. However, the changes do not declined the total value of $\mathrm{BC}$, even increase its value. This is due to land use changes occurring in categories with the low EQF values, namely grazing land into the land use type with a high EQF value, i.e. built-up land. Consequently, BC for humans (residents and tourists) is increasing. In some cases, urbanization (including changes in land use for built-up areas and infrastructures) can be a factor of raciality in small islands (see Farhan and Lim, 2011).

In the local context, this is different, the changes that occur have dropped the yield factor and carrying capacity of the island, so to meet the needs of the population should be imported from the mainland, even for the needs of fish imported from Bali, Sumbawa and Sumba Region. This condition is one of the factors that can increase the vulnerability of the Gili Matra Islands (Kurniawan et al., 2016b). Rees (1992) explained that imports can affect people's lifestyles and improve urbanization, and can reduce and limit local production.

Nowadays, the total local bioproductivity that can be supplied by the Gili Ayer Island, about 0.00857 gha per capita per year, the Gili Meno Island, around 0.20103 gha per capita per year, and the Gili Trawangan Island, about 0.00344 gha per capita year (Table 3 ), far below the average total values $\mathrm{BC}$ of the world, Asia-Africa and Indonesia, i.e. 1.73 gha per capita, 0.9 gha per capita, and 1.3 gha per capita, respectively (GFN, 2016). They show that only a few are bio-ecological supplied by the Gili Matra Islands, and more than $90 \%$ of other needs must be imported. Table 3 shows that the number of tourists were a major factor in the intensity of $\mathrm{BC}$, which almost $100 \%$ must be supplied from outside to the Gili Trawangan Island (0.00346 gha per capita per year of tourists) and the Gili Ayer Island (0.00874 gha per capita per year), while for the Gili Meno Island can only supplied 2\% (0.02044 gha per capita per year tourists), meanwhile the utilization has over carrying capacity. In fact, if seen from the BC of islanders, the island's BC is still large and suppliedble the needs of the communities, only about 30 to $50 \%$ to be imported, especially for te Gili Meno Island, where the BC value of islanders reaches 1.22 gha per capita,which means able to supply their own needs and even can supply other islands around (>1).

Based on the results indicate that Gili Matra Island is in a critical position in $B C$ intensity, both BC per unit area and per capita. The human population density is an important factor of BC intensity and determinant of the carrying capacity of the region based on the maximum consumption of resources and waste (Rees, 1992; Yue et al., 2011). The high value of BC imports can increase the high dependence of an area with other regions (Yue et al., 2011). Continuously, dependency indicates that an area tends to be unsustainable. Although the aspect of economic value is high and able to complete its needs, future development should consider the balance between the bioproductive of land with EF (need), whether it is deficit or still a surplus. For that reason, the social-ecological system approach can be used to look at a small island region comprehensively and the basis for the policy making and sustainable development. In space utilization interventions, technological aspects are crucial in improving spatial function and saving energy and resources.

\section{Conclusions}

The BC of the Gili Matra Islands are in a critical position, both per-unit-area and percapita, where spatially almost $100 \%$ of the demand is supplied from outside the island. This condition shows that the utilization in the Glli Matra Islands is indicated to have exceeded the carrying capacity. The aspects of sustainable development should be applied 
strictly to ensure the sustainability of the natural resources, social, and community's economic, and cotinuously consider the efforts and existing strategies of conservation. Land use management to comply the needs of islanders residences and tourists accomadation, and supporting facilities are urgently needed. In long-term planning, the export and import factors of bioproductivity should also be considered in more detail, and limitations on the use of space must be made.

BC assessment spatially is aplicable to reflect the condition status of the islands. GISbased BC can provide the objective phenomenon of pattern and value distribution, both spatially and temporarily. Nevertheless, the statistical data uses is constantly required to obtain a BC per capita value.

\section{Acknowledgements}

The authors would like to acknowledge the support of Beasiswa Unggulan (Unggulan Scholarship), Ministry of Education and Culture, Higher Education, Republic of Indonesia awarded in 2012 and Global Footprint Network for data provided and permission of its use in publications under Dataset License Agreement (the "Agreement") dated 13/3/2017.

\section{References}

Adrianto, L., Matsuda, Y. 2004. Study on assessing economic vulnerability of small island regions. Environment, Development and Sustainability 6: 317336.

Bagliani, M., Galli, A., Niccolucci, V., Marchettini, N. 2008. Ecological footprint analysis applied to a subnational area: the case of the Province of Siena (Italy). Journal of Environmental Management 86 (2): 354-64.

Borucke, M., Moore, D., Cranston, G., Gracey, K., Iha, K., Larson, J., Lazarus, E., Morales, J.C., Wackernagel, M., Galli, A. 2013. Accounting for demand and supply of the biosphere's regenerative capacity: The National Footprint Accounts' underlying methodology and framework. Ecological Indicators 24 : 518-533.

Bottema, M.J.M., Bush, S.R. 2012. The durability of private sector-led marine conservation: A case study of two entrepreneurial marine protected areas in Indonesia. Ocean and Coastal Management 61: 38-48.

Cornelia, P.G. 2014. True cost economics: Ecological footprint. Procedia Economics and Finance 8: 550-555.

Desa Gili Indah. 2015. Monografi Desa Gili Indah: Tabel Pendataan Kecamatan Pembantu Pemenang, Kabupaten Lombok Utara. Desa Gili Indah, Unpublished Document. Pemenang, Indonesia.

Dinas Pariwisata Kabupaten Lombok Utara. 2015. Pariwisata Dalam Angka Kabupaten Lombok Barat Tahun 2014. Dinas Pariwisata Kabupaten Lombok Utara, Unpublished Document. Tanjung, Indonesia.

Erb, K.-H. 2004. Actual land demand of Austria 1926-2000: a variation on Ecological Footprint assessments. Land Use Policy 21 (3) : 247-259.

Ewing, B., Moore, D., Goldfinger, S., Oursler, A., Reed, A., Wackernagel, M. 2010. The ecological footprint atlas 2010. Global Footprint Network, Oakland.

Farhan, A.R., Lim, S. 2011. Resilience assessment on coastline changes and urban settlements: A case study in Seribu Islands, Indonesia. Ocean and Coastal Management 54: 391-400.

Farhan, A.R., Lim, S. 2012. Vulnerability assessment of ecological conditions in Seribu Islands, Indonesia. Ocean and Coastal Management 65, 1-14.

Galli, A., Wackernagel, M., Iha, K., Lazarus, E. 2014. Ecological footprint: Implications for biodiversity. Biological Conservation $173: 121-132$.

Global Footprint Network (GFN). 2016. National footprint accounts, 2016 Edition. Global Footprint Network, Oakland (US).

Hampton, M.P., Jeyacheya, J. 2014. Power, ownership and tourism in small islands: Evidence from Indonesia. Word Development 70 : 481-495.

Hopton, M.E., White, D. 2012. A simplified ecological footprint at a regional scale. Journal of Environmental Management $111: 279-86$.

Kissinger, M., Rees, W.E. 2010. Importing terrestrial biocapacity: The U.S. case 
and global implications. Land Use Policy 27 (2) : 589-599.

Kurniawan, F., Adrianto, L., Bengen, D.G., Prasetyo, L.B., 2016a. Patterns of landscape change on small islands: A case of Gili Matra islands, marine tourism park, Indonesia. Procedia Social and Behavioral Sciences 227 : 553-559.

Kurniawan, F., Adrianto, L., Bengen, D.G., Prasetyo, L.B. 2016b. Vulnerability assessment of small islands to tourism: The case of the Marine Tourism Park of the Gili Matra Islands, Indonesia. Global Ecology and Conservation 6 : 308-326.

Lin, D., Hanscom, L., Martindill, J., Borucke, M., Cohen, L., Galli, A., Lazarus, E., Zokai, G., Iha, K., Eaton, D., Wackernagel, M. 2016. Working guidebook to the National Footprint Accounts: 2016. Global Footprint Network, Oakland.

Mózner, Z., Tabi, A., Csutora, M. 2012. Modifying the yield factor based on more efficient use of fertilizer-The environmental impacts of intensive and extensive agricultural practices. Ecological Indicators 16 : 58-66.

Niccolucci, V., Tiezzi, E., Pulselli, F.M., Capineri, C. 2012. Biocapacity vs Ecological footprint of world regions: A geopolitical interpretation. Ecological Indicators $16: 23-30$.

Rees, W.E. 1992. Ecological footprints and appropriated carrying capacity: what urban economics leaves out.
Environment and Urbanization 4 (2) : 121-130.

Scotti, M., Bondavalli, C., Bodini, A. 2009. Ecological footprint as a tool for local sustainability: The municipality of Piacenza (Italy) as a case study. Environmental Impact Assessment Review 29 (1) : 39-50.

Shia, C., Hutchinsonb, S.M., Xua, S. 2004. Evaluation of coastal zone sustainability: an integrated approach applied in Shanghai Municipality and Chong Ming Island. Journal of Environmental Management 71 : 335344.

Toderoiu, F. 2010. Ecological footprint and biocapacity - Methodology and regional and national dimensions. Agricultural Economics and Rural Development 2 : 213-238.

Vačkář, D. 2012. Ecological footprint, environmental performance and biodiversity: A cross-national comparison. Ecological Indicators 16 : 40-46.

Wrbka, T., Erb, K.-H., Schulz, N.B., Peterseil, J., Hahn, C., Haberl, H. 2004. Linking pattern and process in cultural landscapes. An empirical study based on spatially explicit indicators. Land Use Policy 21 (3) : 289-306.

Yue, D., Xu, X., Hui, C., Xiong, Y., Han, X., Ma, J., 2011. Biocapacity supply and demand in Northwestern China: A spatial appraisal of sustainability. Ecological Economics 70 (5) : 988-994. 